\title{
Erratum to: Palmitoylcarnitine Affects Localization of Growth Associated Protein GAP-43 in Plasma Membrane Subdomains and its Interaction with $\mathbf{G} \alpha_{0}$ in Neuroblastoma NB-2a Cells
}

\author{
Karolina Tułodziecka $\cdot$ Magdalena Czeredys • \\ Katarzyna A. Nałęcz
}

Published online: 31 August 2013

(C) Springer Science+Business Media New York 2013

Erratum to: Neurochem Res

DOI 10.1007/s11064-012-0944-5

The authors were made aware of an error in the presentation of Fig. 1. One of the blot bands was inadvertently duplicated during the composition of the composite figure. The corrected figure is shown below. The error does not change the described phenomenon nor the description in the text and final conclusions, concerning no effect of neomycin on GAP-43 localization in raft fraction upon palmitoylcarnitine treatment. The authors apologize for the technical error.

The online version of the original article can be found under doi:10.1007/s11064-012-0944-5.

K. Tułodziecka $\cdot$ M. Czeredys $\cdot$ K. A. Nałęcz $(\bowtie)$

Nencki Institute of Experimental Biology, 3 Pasteur Street,

02-093 Warsaw, Poland

e-mail: k.nalecz@nencki.gov.pl 
Control
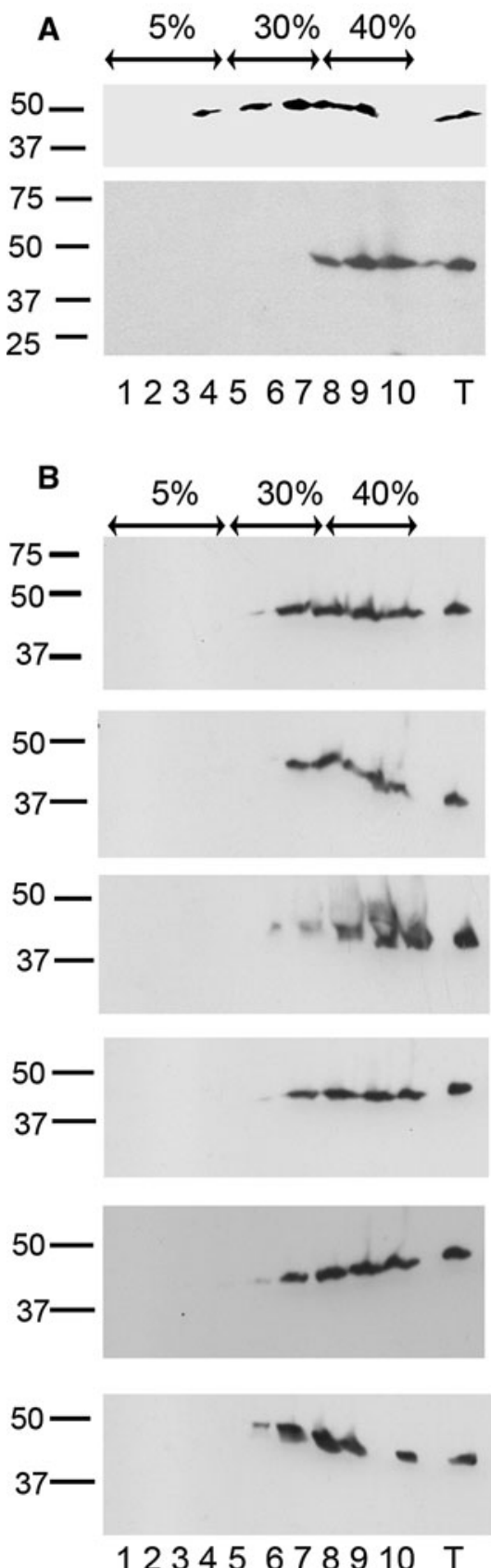

Fig. 1 Distribution of proteins in raft and non-raft domains. NB-2a cells treated with either BSA with ethanol (control) or palmitoylcarnitine coupled to BSA were solubilized in the presence of Triton $\mathrm{X}-100$, as described in "Materials and Methods", and the extract was subsequently subjected to sucrose gradient centrifugation. Fractions collected from the top of the gradient were analysed by Western blot for the presence of proteins typical for microdomains-flotillin-1 and caveolin-1 (a) or for GAP-43 (b). Numbers indicate the fraction numbers collected from the top, $\mathrm{T}$-total extract $(100 \mu \mathrm{g}$ protein)
Flotillin-1

Caveolin-1

GAP-43

No additions

$$
\begin{gathered}
\text { 2-Bromo- } \\
\text { palmitate } \\
1 \mathrm{~h}
\end{gathered}
$$

\section{2-Bromo- palmitate $96 \mathrm{~h}$}

Etomoxir

$M \beta C D$

Neomycin
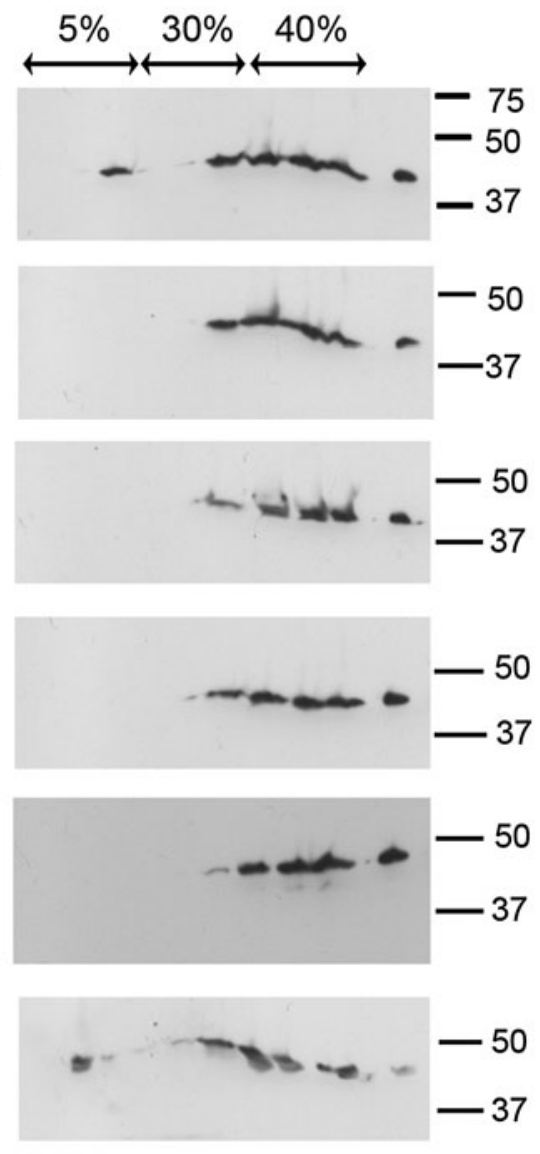

\section{$12345678910 \quad \mathrm{~T}$}

\section{Palmitoylcarnitine}

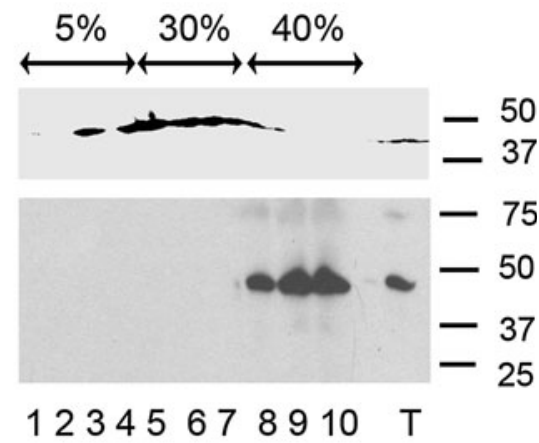

loaded as a reference. b Detection of GAP-43 after 96-h incubation without (control) or with palmitoylcarnitine either without any further additions or after treatment with $100 \mu \mathrm{M}$ 2-bromopalmitate $(96 \mathrm{~h})$, $100 \mu \mathrm{M}$ etomoxir $(96 \mathrm{~h}$ ), $100 \mu \mathrm{M}$ neomycin (last $24 \mathrm{~h}$ ) or $10 \mathrm{mM}$ methyl- $\beta$-cyclodextrin-MbCD (last $1 \mathrm{~h}$ ). Distribution of GAP-43 under control conditions and after palmitoylcarnitine treatment was verified for each centrifugation, and all other experiments and gradient analyses were performed at least three times 